\title{
The Effect of Human Capital on the Role of the Board of Commissioners
}

\section{Makaryanawati ${ }^{1}$}

\author{
${ }^{1}$ Malang State University, Indonesia, e-mail: Makaryanawati.fe@um.ac.id
}

\begin{abstract}
This study aims to provide empirical evidence of the influence of human capital on the monitoring and the advising role of the board of commissioners. The monitoring of management behavior is needed because of the separation of authority between the shareholder and manager. One of the roles of monitoring is the monitoring of financial statements presented by management. In addition to monitoring, the board of commissioners plays a role in providing strategic advice to formulate corporate strategies and policies. The population is manufacturing companies listing on the Indonesia stock exchange for the period 2008-2014. Sampling using a purposive sampling method and obtained 792 observations. Processing and analyzing data using the Partial Least Square. The findings of this study indicate that human capital influences the monitoring and the advising role of the board of commissioners. This proves that the human capital of the board of commissioners is indispensable in supporting the implementation of roles. The level of knowledge, experience, and expertise of the board of commissioners that is adequate can reduce earning management and increase profitable investment for the company. Thus, when a company chooses a board of commissioners it is necessary to consider human capital.

Keywords: Human Capital, Monitoring Role, Advising Role
\end{abstract}

\section{Introduction}

Management of a company cannot be separated apart from the role of the board of commissioner, especially in the capital market of developing countries (emerging markets) like Indonesia. When external control mechanism is regarded ineffective and legal protection over investors is still weak, internal control mechanisms which involve the roles of the board of commissioners become an important element for a company to avoid conflicts of interest among stakeholders (Young et al., 2008). The board of commissioners plays an important role within a company including the role in connecting shareholders with other stakeholder groups (Pass, 2004); monitoring corporate performance and providing advice and supervisory to the board of directors (Jungmann, 2006).

One of the responsibilities of the board related to monitoring is to make an assessment upon the quality of the reported information. The effectiveness of monitoring which is reflected by independence which can be assessed through the level of income reported by the company management. The number of the independent board of commissioners in companies will tighten the role of monitoring, by which it is expected that the earning management will be decreased while the income quality increases (Benkel et al., 2006, Jaggi et al., 2009, Kim et al., 2014). Furthermore, the independent board of commissioners should be able to make sure that the monitoring role is smoothly carried out (Chou et al., 2013), while at the same time enhancing the role of advising by giving different views on value (Brickley and Zimmerman, 2010).

Internal support is necessary to support the board of commissioners in carrying out its roles. Internal support refers to an individual's intellectual ability in the board of commissioners. Generally, the board of commissioners has different capabilities from one another, making the board of commissioners' attributes group diverse. The board of commissioners has the ability to create the corporate value of a company. A number of researches have been conducted focusing on the attention towards experience and education (Lin and Huang, 2005, Reeb and Zhao, 2013), routines and procedures (Donaldson and Davis, 1994), relational aspects (Al-Musalli and Ismail, 2012) and the towards information (Pfeffer and Salancik, 1978). Those aspects concerned many researchers as they are the elements of intellectual capital within the board of commissioners. 
One of the intellectual capitals possessed by the board of commissioners is human capital. Human capital is an important element in creating value through investment in knowledge, expertise, talent, and experience. Intellectual capital applied in work can create value (Williams, 2001). This value can be seen from the effectiveness of the role of the board of commissioners. Thus, knowledge, experience, and expertise of the board of directors will contribute to the effectiveness of directors' roles, including the role of monitoring and the role of advising.

Agency Theory. Agency theory closely relates to work cooperation between a party that holds an authority (principal) and a party that receives the authority (agent) with different interests. Eisenhardt (1989) describes the domain of agency theory as a relationship that reflects the structure of the basic agency between two parties (principals and agents) involved in the cooperation contract. This mutually agreed contract determines each party's rights and obligations. This framework functions as a contract liaison between various parties to coordinate a number of resources in such ways to achieve specific objectives. Principals delegate their authority and responsibilities related to decision making to agents. However, conflicts of interest often occur between those parties, leading to various risks that should be anticipated by the company.

Different interests driven by opportunistic management need to be carefully supervised by the board of commissioners as the authorized party deal with the interests of shareholders. This condition requires effective roles of monitoring and control from the board of commissioners in order to prevent the management from prioritizing personal welfare which might harm the company. Thus, the role of monitoring shares significant relevance to the agency theory.

Resources Dependence Theory. Resource dependency theory was first introduced by Pfeffer and Salancik (1978). This theory identifies companies as open systems that depend on external environmental contingencies. To reduce the dependency on the external environment and the need for critical resources, companies need adequate roles of the board of commissioners, one of which is the role of providing access to various resources. Duztas (2008) states that the resource selection gives significant implications to the role and structure of the board of commissioners as the board of directors holds the role as a mechanism that establishes relationships with the external environment. The company's need for strategic resources, for example, information, can be obtained by the board of commissioners through intensive advisory toward the company management. In maintaining the corporate operation, company management needs valuable insights and different perspectives from the board of commissioners.

The Role of the Board of Commissioners. The board of commissioners holds three important roles that should be widely supported (Zahra and Pearce, 1989). The roles of the board of commissioners in controlling and monitoring management are important since company ownership is separated from corporate control. The role of the board of commissioners tends to dominate the existing literature due to the increasing legislation the emergence of agency theory (Eisenhardt, 1989). The second role is the board's active involvement in the form of strategic advisory to the company management and the third role describes the role of the board of commissioners in providing access to resources, including confidential company information (Pugliese et al., 2014), improving company's reputation, stabilizing the relationship with the external environment, as well as advising the executives (Zahra and Pearce, 1989). The last two roles refer to the perspective of resource dependence.

Supervision toward company management is necessary as it is the consequence resulted in duty separation between shareholders and company managers. Supervision is done to many aspects, one of which is on financial statement reports. Financial statements are a means of management accounting that is very vulnerable to manipulation. Likewise, due to the limited knowledge, insight, experience in the board of directors, advice from the board of commissioners is necessary for determining the company's strategic policies.

Human Capital. In relation to the effectiveness of the board of commissioners' role in improving corporate performance, it is necessary to regard intangible resources attached in every individual in the board. Human capital is one of these resources. Human capital refers to an individual's level of 
knowledge and skills that are specifically improved through various investment in education, training, and various experience. Human capital can be obtained through formal education, experience and practical learning in the workplace (Davidsson and Honig, 2003).

Hypothesis. Human capital influences the activities of the board of commissioners as an individual's experience and expertise affect the cognition and decisions making (Johnson et al., 2013). Similarly, Khanna et al. (2014) believe that better quality of human capital significantly improves corporate performance in the following year. This might be caused an improvement in the human capital within the board of commissioners will increase the ability to monitor the work of company management and prevent the management from performing opportunistic actions that might harm the company. In connection with the monitoring role, the board of commissioners also runs the function of an internal control mechanism as the representative of stakeholders. The board of commissioners must establish strong independence in disciplining the managerial decision making and this is usually owned by the outside director (Kosnik, 1990). The formal independence of the outside director is assumed to provide more objective assessment toward the board's involvement in strategic decision making (Johnson et al., 1993), and it is expected to improve the monitoring and control process (Westphal, 1999).

Some researchers state that in expanding the involvement of the board of directors in a company in addition to the monitoring role, the board of commissioners should provide valuable advisory related to the company's strategic problems (Zahra and Pearce, 1989). In carrying out this role, it is necessary for the board of commissioners to have a strong intellectual ability. Providing advice to management requires special knowledge and experience (working period/tenure) of the board of commissioners (Kim et al., 2014), as well as financial expertise (Faleye et al., 2011, Faleye et al., 2013).

Emphasis on the effectiveness of the board of directors in dealing with shareholders' interest can be done by monitoring and evaluating the managerial performance. Supervision of managerial performance requires special knowledge and experience related certain particular industry. This supports the belief that diverse knowledge and experience in specific industries and the length of work for companies can determine the role of the board of commissioners in assessing, providing information and influencing management actions. In accordance with a research conducted by Carpenter and Westphal (2001) and Xie et al. (2003), board of commissioners' experience as company executives in other companies and special expertise in understanding various works improve the effectiveness of the monitoring role which will be beneficial in solving various potential problems in a better way (Reeb and Zhao, 2013).

Based on the description above, the research hypothesis can be formulated as follows:

H1: Human capital influences the board of commissioners' role in monitoring.

H2: Human capital influences the board of commissioners' role of advising.

\section{Research Methodology}

The population of this study was all manufacturing companies listed in the Indonesian Stock Exchange (IDX) in 2008-2014. The limitation of this population was set to avoid biases that might be caused by differences in company characteristics. The observation period was determined as such since, in October 2006, Indonesia has just revised the principles and rules of corporate governance adopted from the OECD (Organization for Economic Co-operation and Development). The implementation of these principles and rules was effectively carried out in 2007 and 2008. Hence, the impacts of the implementation of these principles could only be analyzed in 2008 (Ghofar, 2013).

Samples were selected using the purposive sampling method. The first sampling criteria were related to the availability of companies' annual reports for the 2008-2014. Second, the company's annual reports should present information related to the profile of the board of commissioners and the financial data needed. There were 792 samples selected in this research.

The data obtained in this research were in the form of financial data summary, a summary of financial statements and annual reports of the year 2007-2014 from Indonesian Capital Market Directory 
(ICMD), OSIRIS website, company website, and IDX website. The data intended in this research were the ones about the profile of the board of commissioners including education background, work experience, expertise; and accounting data.

Human capital is one's inherent intellectual capital which in this research refers to the ones of the company board of commissioners. The quality of the human capital among the board of directors is seen as a source of competitive advantage, which contributes to achieving the effectiveness of the monitoring role and the role of giving advice (Khanna et al., 2014). The human capital theory argues that a person will make rational choices related to his desire to invest time, effort and finances in education, training, and experience (Lin and Huang, 2005) to maximize welfare and other benefits in the future.

The term human capital is often used interchangeably with the term's knowledge, experience, and skills. Hence, the indicators of human capital measurement in this study were the aspects related to knowledge (Reeb and Zhao, 2013, Lin and Huang, 2005, Felicio et al., 2014), experience (Reeb and Zhao, 2013, Lin and Huang, 2005, Felicio et al., 2014, Johnson et al., 2013) and expertise (Duchin et al., 2010).

One's knowledge was be measured by the level of education of the board of commissioner members (bachelor, master, doctorate). Education is generally used as an attribute related to human capital as it does not only reflect one's knowledge, but also the level of individual intelligence. The measurement of one's level of education was adapted from Reeb and Zhao research (2013) in which grades are given for each level of education (non-degree / below undergraduate level = 0 ; undergraduate $=1$; master $=2$; doctorate $=3$ ) for each individual. After the scores are given to each member of the board of commissioners, the scores are summarized to obtain the average score of the board of commissioners whose average score shows the general level of education of the board of commissioners in each company.

Human capital is not merely developed through formal education, but it can also be improved through experiences. In this research, the indicators used to measure one's experience was the duration of work (tenure) (Lin and Huang, 2005, Johnson et al., 2013, Kor and Sundaramurthy, 2009, Davidsson and Honig, 2003). The board of commissioners must understand the internal company characteristics and conditions in order to be able to evaluate management's actions and to provide valuable contributions to the formulation of the company's strategy. Work tenure was shown by the average year of work.

Furthermore, expertise was measured from the background of expertise owned by the board of commissioners (board's expertise). Duchin et al. (2010) measured the expertise variable of the board of commissioners using three qualifications, namely academic qualification, corporate qualification, financial qualification. In this research, indicators of expertise were adapted from Duchin et al. (2010) and Ghofar (2013). Academic qualification showed one's position whether as a professor or lecturer in a university. Corporate qualifications indicated that the board of directors was an executive at another company. Financial qualifications indicated whether the board of commissioners has certain expertise or certification related to accounting or finance, for example as bankers, investment bankers, venture capitalists in other companies or whether they owned a Chartered Accountant, Certified Public Accountant, Certified Management Accountant, Chief Financial Officer, Certified Financial Analysis or other financial expertise degree (Kim et al., 2014). The indicators of expertise were measured using this following formulation:

Board's Expertise $=\sum \frac{\sum \text { score of each member's qualification }}{\sum \text { number of commissioner members }}$

The monitoring of the financial statement transparency is under the responsibilities of the board of commissioners. The failure in overseeing transparency of financial statements is indicated by the manipulation of the corporate earnings report. Management actions to modify the earning are known 
as earning management. The higher earnings management conducted by management means that the role of the board of directors in supervising management actions is ineffective.

In this research, earning management was measured by calculating discretionary accruals as a proxy for the effectiveness of the monitoring role as suggested by the study of Kim et al. (2014). Referring to the advantages and disadvantages of several earnings' management estimation models, the performance matched discretionary accruals were employed in this research (Kothari et al., 2005) which is the development of the modified Jones' model, in which financial performance is regarded(lag ROA). The following equation was used to calculate the discretionary accruals.

1. Calculating the total accrual:

$\mathrm{TA}_{\text {it }}=\mathrm{NI}_{\mathrm{it}}-\mathrm{CFO}_{\mathrm{it}}$

Note:

$\mathrm{TA}_{\text {it }}=$ Total accrual company I in year $\mathrm{t}$.

$\mathrm{N}_{\text {uit }}=$ Net income before extraordinary account and termination of operation by the company I in year $\mathrm{t}$

$\mathrm{CFO}_{\text {it }}=$ Cash flow operation of a company $\mathrm{I}$ in year $\mathrm{t}$.

2. Determining the regression coefficient of the total accrual

$\left.\mathrm{TA}_{\mathrm{it}} / \mathrm{A}_{\mathrm{it}-1}=\alpha\left(1 / \mathrm{A}_{\mathrm{it}-1}\right)+\beta 1\left(\left(\Delta \mathrm{REV}_{\mathrm{it}}-\Delta \mathrm{REC}_{\mathrm{it}}\right) / \mathrm{A}_{\mathrm{it}-1}\right)\right)+\beta 2\left(\mathrm{PPE}_{\mathrm{it}} / \mathrm{A}_{\mathrm{it}-1}\right)+\beta 3\left(\mathrm{ROA}_{\mathrm{it}}-1 / \mathrm{A}_{\mathrm{it}-1}\right)+\varepsilon_{\mathrm{it}}$ Note:

$\mathrm{TA}_{\mathrm{it}} \quad$ : Total accrual of company $\mathrm{i}$ in year $\mathrm{t}$.

$\mathrm{A}_{\mathrm{it}-1}$ : Total asset of the company I at the end of year $\mathrm{t}-1$.

$\Delta \mathrm{R}_{\text {evit: }}$ Changes in net sales of the company $\mathrm{I}$ in year $\mathrm{t}$.

$\triangle \mathrm{REC}_{\mathrm{it}}$ : Changes in net receivables of the company I in year $\mathrm{t}$.

$\mathrm{PPE}_{\mathrm{it}}$ : Property, plant, and equipment of company I in year $\mathrm{t}$.

$\mathrm{ROA}_{\mathrm{it}-1}$ : Return On Assets of the company I at the end of year $\mathrm{t}-1$.

it: error term of the company $i$ in year $t$.

Discretionary accrual values were obtained by measuring the regression of the above formulation to determine the error value. The regression of each company was estimated based on 48 industrial classifications of Fama-Frech. The population of this research included manufacturing industries listed in the Indonesian Exchanges. Hence, the industrial classification was adjusted to the classification of 19 sub-sectors of manufacturing industries in the Indonesian Capital Market Directory (ICMD).

Discretionary accrual value with a positive sign indicates that the company performed income increasing, and the one with a negative sign indicates that the company did not perform income increasing. Both signs indicate that the company did earnings management. Thus, the monitoring role of the board of commissioners which is proxied by earnings management by company executives was measured through the absolute value of discretionary accruals. The greater the absolute value of discretionary accruals, the higher earnings management implying that the monitoring role is less effective. There is a reverse relationship between the monitoring role variable and the proxy used to measure it.

Advising role is one of the board of commissioners' roles in which they are required to give suggestion and independent analysis to company managers. The advising covers insights on various corporate strategic policies. The strategic policies include policies to do acquisition, merger and various policies related to investment. The management also needs the insights and suggestions from the board of the commissioners to decide the best investment decision, which is predicted to give profit for the company. The selection of investment products that give positive benefits to the company reflects that the board of commissioners has succeeded in performing their advising role. On the other hand, the investment that gives negative results shows that the board of commissioners has not yet performed an effective advising role. Therefore, the advising role is proxied by investment policies taken by a company (Kim et.al., 2014). 
This investment policy is used to evaluate the benefits obtained from the investment, while the expected investment income is measured by investment residuals as suggested by (Kim et al. (2014), Biddle et al., 2009). Investment efficiency is measured by calculating the deviation of the expected investment using the model that predicts investment as a function of growth opportunity (Chen et al., 2011). Company growth opportunity is reflected in sales growth. Thus, investment efficiency is the function of sales growth.

The deviation of the expected investment is shown in the residual investment value (error value). Investment residuals with positive value (over-investment) indicate that the investment made by a company has exceeded the expected investment and vice versa. Investment residuals were calculated as follows.

$$
\text { Investmenti, } \mathrm{t}=\alpha 0+\alpha 1 \text { Sales Growthi, } \mathrm{t}+\varepsilon_{\mathrm{i}, \mathrm{t}}
$$

Note:

Investment $_{\mathrm{I}, \mathrm{t}}=$ Summary of the research and development expense, capital expenditure and acquisition expense minus the net sales of plant, property, and equipment (PPE) of the company I in year $t$. The result of the above calculation was then divided by the lagged total asset (TA) times 100. Mathematically, the formula used to calculate the total investment is presented as follows:

$=\underline{(\mathrm{R} \& \mathrm{D}+\text { Capex }+ \text { Acquisition }- \text { Net sales PPE })}$ X 100

$\mathrm{TA}_{\mathrm{t}}-\mathrm{TA}_{\mathrm{t}-1}$

Sales Growth= Percentage of changes in sales from year $t-1$ to year $t$ of the company $\mathrm{I}$ in year $\mathrm{t}$. $=$ Sales $_{\mathrm{t}} /$ Sales $_{\mathrm{t}-1}$

$\varepsilon_{i t} \quad=$ Error term of the company $\mathrm{i}$ in year $\mathrm{t}$.

After the data regarding the company investment and growth had been obtained, the investment residuals values were calculated. Investment residual values were obtained by measuring the regression of the above formulation to determine the error value.

\section{Result and Discussion}

The data obtained in this study were analyzed using Partial Least Square (PLS). The data analysis included descriptive statistics analysis and hypothesis testing. Hypothesis testing was carried out to examine the strength and direction of the influence between variables in the structural model. The model was first evaluated prior to the hypothesis testing which PLS was done in two stages; evaluation of the outer model and the evaluation of the inner model. Evaluation of the outer model aimed to test the validity and reliability of the construct variables, in addition to representing the construct parameters built from conceptual frameworks of research and empirical studies.

Evaluation of the outer model for formative indicators was conducted by considering the significance of the outer weight calculation results, which described the contribution of each indicator to its latent variable. The estimated value for the formative measurement model must be statistically significant indicated by the t-statistic value that must be greater than 1.96 in the two-tailed hypothesis (twotailed) in $5 \%$ alpha test. The outer model that was carried out in this study was the one related to the variable of human capital. The outer model equation is stated as follows:

$\mathrm{HC}=\lambda_{1} \mathrm{KNOW}+\lambda_{2} \mathrm{EXP}+\lambda_{3} \mathrm{SKL}+\delta_{1}$

Evaluation of the inner model was done in several stages, including testing the relationship between constructs, which can involve the value of the t-test (critical ratio) obtained from the bootstrapping process. Next, the $\mathrm{R}^{2}$ value was calculated to see whether the influence of exogenous latent variables on endogenous latent variables had any substantive effect. The inner model equation is shown as follows:

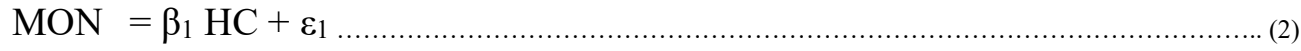

$\mathrm{ADV}=\beta_{2} \mathrm{HC}+\varepsilon_{2}$

Note: 


$\begin{array}{ll}\mathrm{HC} & =\text { Human Capital } \\ \mathrm{KNOW} & =\text { Knowledge } \\ \mathrm{EXP} & =\text { Experience } \\ \mathrm{SKL} & =\text { Skill } \\ \mathrm{MON} & =\text { Monitoring role } \\ \mathrm{ADV} & =\text { Advising role } \\ \lambda_{\mathrm{i}} & =\text { Outer weight of each formative indicator } \\ \beta \mathrm{i} & =\text { Path coefficient of each variable } \\ \varepsilon_{\mathrm{i}} & =\text { Residuals/ unanalyzed factors }\end{array}$

Descriptive statistics explains the varied characteristics of research that includes the minimum and maximum value, mean and the standard of deviation. The results of the descriptive statistic test conducted to each variable and indicator of 792 observed samples in this research are presented in Table 1.

Table 1. The Descriptive Statistics of the Research Variables

\begin{tabular}{|c|l|r|r|r|r|}
\hline No. & \multicolumn{1}{|c|}{ Variable } & \multicolumn{1}{c|}{ Minimum } & Maximum & Average & $\begin{array}{c}\text { Standard of } \\
\text { Deviation }\end{array}$ \\
\hline 1. & Human Capital & & & & \\
& Knowledge & 0.000 & 3.000 & 1.272 & 0.551 \\
& Experience & 1.000 & 25.667 & 8.214 & 5.067 \\
& Expertise & 0.333 & 2.500 & 1.368 & 0.396 \\
\hline 2. & Monitoring Role & 0.001 & 5.412 & 0.590 & 0.643 \\
\hline 3. & Advising Role & -1.970 & 8.724 & 0.082 & 0.997 \\
& & & & & \\
\hline
\end{tabular}

Source: Processed Data

The path equation in the PLS model has divided into two parts; the outer model and the inner model. The evaluation of the outer model for formative indicators was done by considering the significance of the results of outer weight calculation. This test was considered necessary to confirm that each indicator possesses the required converging validity. Convergent validity for formative indicators was measured based on the t-statistic value, where t-statistic value greater 1.96 than t-table implies that the instruments have fulfilled the convergent validity. The results of the convergent validity testing are presented in the following table.

Table 2. Convergent Validity Test

\begin{tabular}{|c|c|c|c|}
\hline & Loading & t-statistic & Note \\
\hline $\mathrm{KNOW} \rightarrow$ Human Capital & 0.425 & 3.480 & Significant \\
\hline $\mathrm{EXP} \rightarrow$ Human Capital & -0.012 & 0.092 & Non-Significant \\
\hline $\mathrm{SKL} \rightarrow$ Human Capital & 0.848 & 9.128 & Significant \\
\hline $\mathrm{DA} \rightarrow$ Monitoring Role & 1.000 & - & Fixed \\
\hline Res.Inv $\rightarrow$ Advising Role & 1.000 & - & Fixed \\
\hline
\end{tabular}

Source: PLS Output 
The t-value of resulted from the analysis of each indicator showed value grater 1.96 for human capital variable including the knowledge (KNOW) of 3.480 and expertise (SKL) of 9.128. However, the tvalue of the experience (EXP) was 0.092 smaller than 1.96. Formative indicators that are not significant do not need to be omitted from the construct to do the test. Theoretically insignificant indicators can be further tested in an inner model. Meanwhile, the significant formative indicators indicate that knowledge and expertise are able to form human capital. The measurement equation model equation was formulated as follows:

$$
\mathrm{HC}=0.425 \mathrm{KNOW}-0.012 \mathrm{EXP}+0.848 \mathrm{SKL}+\delta_{1}
$$

The inner model in this research was constructed by three variables; human capital (exogenous variable), monitoring role (endogenous variable) and advising variable (endogenous variable). This inner model was used to examine the coefficient of the human capital in influencing the monitoring and advising roles. The following equation was the results of the structural model testing.

$$
\begin{aligned}
& \mathrm{MON}=-0.135 \mathrm{HC}+\boldsymbol{\varepsilon}_{1} \\
& \mathrm{ADV}=0.188 \mathrm{HC}+\boldsymbol{\varepsilon}_{2} \ldots
\end{aligned}
$$

Besides to obtain the inner model equation, the goodness of fit inner model testing was also administered to measure the determination coefficient value of the endogenous variables in this research.

Table 3. Determination Coefficient Test

\begin{tabular}{|l|c|}
\hline \multicolumn{1}{|c|}{ Endogenous Variable } & R Square \\
\hline Monitoring Role & 0.017 \\
\hline Advising Role & 0.052 \\
\hline
\end{tabular}

Source: PLS Output

The monitoring role is influenced by human capital at a determination coefficient $\left(\mathrm{R}^{2}\right)$ of 0.017 . This shows that $1.7 \%$ of the monitoring role factors are influenced by human capital. The advising role is influenced by human capital with a determination coefficient $\left(\mathrm{R}^{2}\right)$ of 0.052 . This result indicates that $5.2 \%$ of the advising role is influenced by human capital.

The basis of the hypothesis testing conclusion was the t-value. $t$-value greater than t-table 1.96 indicated a significant influence. The following table shows the interpretation of the results of the hypothesis testing based on the PLS model obtained in this research.

Table 4. The Result of Hypothesis Testing Between Variables

\begin{tabular}{|c|c|c|c|}
\hline Hypothesis & Influence & Coefficient & T Statistic (p-value) \\
\hline 1 & $\begin{array}{c}\text { Human Capital } \rightarrow \\
\text { Monitoring Role }\end{array}$ & -0.135 & $3.099(0.001)$ \\
\hline 2 & $\begin{array}{c}\text { Human Capital } \rightarrow \\
\text { Advising Role }\end{array}$ & 0.231 & $6.494(0.000)$ \\
\hline
\end{tabular}

Source: Processed Data

The result of the first hypothesis (H1) testing shows that human capital negatively affects earnings management, which is a proxy for monitoring roles. The effectiveness of the monitoring role was measured by the presence and absence of earnings management in companies, as measured by the absolute value of discretionary accruals. Between the monitoring role variables and the proxies used, earnings management is inversely proportional. The greater the earnings management, the less effective the monitoring role, and vice versa. In relation to the results of the negative hypotheses testing, better human capital in the board of commissioners will reduce earnings management, indicating a more effective monitoring role carried out by the board of commissioners.

The results of this study are consistent with the findings of research conducted by Carpenter and Westphal study (2001) and Xie et al. (2003), in which it is found that the experience of the board of 
commissioners will help in certain situations and work experience as executives in other companies and social expertise of the board of commissioners in understanding the work enhance the monitoring role. The board of commissioners with the adequate corporate or financial background is related to low discretionary accruals. The monitoring role of the board of commissioners will be more effective when the board of commissioners has adequate financial expertise.

Similarly, Kim et al. (2014) have proven that the financial expertise of the board of commissioners shares negative influence both discretionary accruals and the total accruals. This finding shows that adequate financial skill of the board of commissioners minimizes earning management, indicating better effectiveness of the monitoring role. The members of the board commissioner who have adequate financial skills will find it easier in controlling the behavior of company management, preventing the management from performing any income manipulation.

Some researchers share different argumentation related to this hypothesis. First, the education background of the board of commissioners might give a certain contribution to the monitoring of the financial report. Higher education level reflects more adequate knowledge and information, making the cognitive competence of the board of commissioners better. This condition creates more effective monitoring toward company management behaviors. Higher education level is believed to reflect ones' level of intellectuality which affects their competence in running a certain role.

Second, the capability of the board of commissioners analyzed in this research included the academic qualification, corporate qualification, and financial qualification. Those three qualifications support better human capital of the board of commissioners. Financial monitoring requires adequate accounting and financial skills which skills are mostly owned by the majority of samples involved in this research. Based on the result of the descriptive statistics analysis shows that averagely, the board of commissioner members have one or two skills. This shows stronger human capital that supports the monitoring of corporate financial statements.

The result of the second hypothesis (H2) testing shows that human capital positively influences the advising role of the board of commissioners. The result of this study supports the finding of previous research stating that longer tenure which proxies the work experience and specific corporate knowledge obtained through the time which decreases information asymmetry between the board of commissioners and the company management, leading to better advising role (Kim et al., 2014). Longer work experience in a company allows the board of commissioners to understand various strengths, weaknesses and upcoming opportunities and challenges. Hence, the board of commissioners will be able to give proper advisory for the company management to make a better decision.

High education level, the breadth of work experience and the expertise of the board of directors are closely related to ones' intellectual ability to learn and process various information. Adequate knowledge, work experience, and expertise will improve communication and discussion ability with other parties, both within the company and external companies. In addition, adequate expertise in a certain specific field and highly valued professional experience (such as entrepreneurial background, CEO experience, and long tenure) allow the board of commissioners to provide useful advice during strategy formulation and create good strategic decisions. For example, when the board of commissioners is required to provide advice regarding the optimum dividend policy, the board of commissioners must understand the investment opportunity set of the company at first.

This finding confirms the opinion of Coles et al. (2012) that in order to provide useful advisory, the board of commissioners requires adequate talent, experience, perspective, and expertise. Similar to the opinion of Faleye et al., $(2011,2013)$ that financial expertise is needed in providing advice to company management.

The crucial role of the board of commissioners requires the board to have adequate intellectual competence. These crucial roles include providing advice to company management, providing various resources and establishing a strong network. This role refers to the resource's dependence theory perspective, which assumes that the board of commissioners is a corporate instrument that 
provides important information and necessary resources and reduces the dependency on the external environment.

\section{Conclusion}

This research has successfully examined the monitoring role and the advising role of the board of commissioners in terms of the intellectual ability of the board of commissioners. Members of the board of commissioners who have sufficient knowledge, experience and expertise (as indicators of human capital) are able to minimize the occurrence of earning management by the board of company managers. The decline in the occurrence of earnings management indicates that the monitoring role carried out by the board of commissioners has been effective. In addition, the board of commissioners with adequate human capital is able to provide strategic advice to management. This indicator was measured from the investment policy made by the company to exceed the targeted return. It can be concluded that human capital is an aspect that strongly influences the role of the board of commissioners, both the monitoring role and advising role.

The results of this study confirm that agency problems arise due to the separation of authority between owners and managers in a company, which problem can be minimized by high intellectual ability. Likewise, the need for external resources and efforts to reduce the dependency on the external environment can be facilitated by adequate involvement of the board of commissioners in the company. The results of this study confirm the agency theory as the basis monitoring role. This research also confirms that the resource dependency theory is the basis of the advising role.

Regarding the results of this research supporting that human capital can influence the role of the board of commissioners, companies are suggested to regard the intellectual ability of the board of commissioners during employee recruitment. This becomes an important aspect because the intellectual ability of the board of commissioners plays a role in increasing the role effectiveness of the board of commissioners. Companies need to pay attention to the level of education and expertise of the board of commissioner members including financial expertise and expertise in a specific field related to industries.

\section{References}

AL-MUSALLI, M. A. K. \& ISMAIL, K. N. I. K. 2012. Intellectual Capital Performance and Board Characteristics of GCC Banks. Procedia Economics and Finance, 2, 219-226.

BENKEL, M., MATHER, P. \& RAMSAY, A. 2006. The Association Between Corporate Governance and Earnings Management: The Role of Independent Directors. Corporate Ownership \& Control, 3, 65-75.

BERGHE, L. A. A. V. D. \& BAELDEN, T. 2005. The Complex Relation Between Director Independence and Board Effectiveness. Corporate Governance, 5, 58-83.

BIDDLE, G. C., HILARY, G. \& VERDI, R. S. 2009. How Does Financial Reporting Quality Relate to Investment Efficiency? Journal of Accounting and Economics, 48, 112-131.

BRICKLEY, J. A. \& ZIMMERMAN, J. L. 2010. Corporate Governance Myths: Comments on Armstrong, Guay, and Weber. Journal of Accounting and Economics, 50, 235-245.

CARPENTER, M. A. \& WESTPHAL, J. D. 2001. The Strategic Context of External Network Ties: Examining The Impact of Director Appointments on Board Involvement in Strategic Decision Making. Academy of Management Journal, 4, 639-660.

CHEN, F., HOPE, O.-K., LI, Q. \& WANG, X. 2011. Financial Reporting Quality and Investment Efficiency of Private Firms in Emerging Markets. The Accounting Review, 86, 1255-1288.

CHOU, H.-I., CHUNG, H. \& YIN, X. 2013. Attendance of Boards Meetings and Company Performance: Evidence from Taiwan. Journal of Banking \& Finance, 37, 4157-4171.

COLES, J. L., DANIEL, N. D. \& NAVEEN, L. 2012. Board Advising. Temple University and Drexel University. 
DAVIDSSON, P. \& HONIG, B. 2003. The Role of Social and Human Capital Among Nascent Entrepreneurs. Journal of Business Venturing, 18, 301-331.

DONALDSON, L. \& DAVIS, J. H. 1994. Boards and Company Performance-Research Challenges the Conventional Wisdom. Corporate Governance: An International Review, 2, 151-160.

DUCHIN, R., MATSUKAKA, J. G. \& OZBAS, O. 2010. When Are Outside Directors Effective? Journal of Financial Economics, 96, 195-214.

DUZTAS, S. 2008. Corporate Governance: The Effects of Board Characteristics, Information Technology Maturity, and Transparency on Company Performance. Philosophy of Doctor Thesis, Yeditepe University Graduate Institute of Social Sciences.

EISENHARDT, K. M. 1989. Agency Theory: An assessment and Review. The Academy of Management Review, 14, 57-74.

FALEYE, O., HOITASH, R. \& HOITASH, U. 2011. The Cost of Intense Board Monitoring. Journal of Financial Economics, 101, 160-181.

FALEYE, O., HOITASH, R. \& HOITASH, U. 2013. Advisory Directors.

FELICIO, J. A., COUTO, E. \& CAIADO, J. 2014. Human Capital, Social capital and Organizational Performance. Management Decision, 52, 350-364.

GHOFAR, A. 2013. Analysis of the Determinants and Effectiveness of Corporate Governance: A Contingency Theory Approach. Doctor of Business Administration, Victoria University.

HARTONO, J. 2011. Konsep dan Aplikasi Structural Equation Modeling, Yogyakarta, UPP STIM YKPN.

JAGGI, B., LEUNG, S. \& GUL, F. 2009. Family Control, Board Independence and Earnings Management: Evidence Based on Hong Kong Firms. J. Account. Public Policy, 28, 281-300.

JOHNSON, R. A., HOSKISSON, R. E. \& HITT, M. A. 1993. Board of Director Involvement in Restructuring: The Effects of Board Versus Managerial Controls and Characteristics. Strategic Management Journal, 14, 33-50.

JOHNSON, S. G., SCHNATTERLY, K. \& HILL, A. D. 2013. Board Composition Beyond Independence: Social Capital, Human Capital, and Demographics. Journal of Management, 39, 232-262.

JUNGMANN, C. 2006. The Effectiveness of Corporate Governance in One-Tier and Two-Tier Board Systems: Evidence from the UK and Germany. ECFR, 4, 426-474.

KHANNA, P., JONES, C. D. \& BOIVIE, S. 2014. Director Human Capital, Information Processing Demands, and Board Effectiveness. Journal of Management, 40, 557-585.

KIM, K., MAULDIN, E. \& PATRO, S. 2014. Outside Directors and Board Advising and Monitoring Performance. Journal of Accounting and Economics, 57, 110-131.

KOR, Y. Y. \& SUNDARAMURTHY, C. 2009. Experience-Based Human Capital and Social Capital of Outside Directors. Journal of Management, 35, 981-1006.

KOSNIK, R. D. 1990. Effects of Board Demography and Directors' Incentives on Corporate Greenmail Decisions. Academy of Management Journal, 33, 129-150.

KOTHARI, S. P., LEONE, A. J. \& WASLEY, C. E. 2005. Performance Matched Discretionary Accrual Measures. Journal of Accounting and Economics, 39, 163-197.

LAWLER, E. E., BENSON, G. S., FINEGOLD, D. I. \& CONGER, J. A. 2002. Corporate Boards: Keys to Effectiveness. Organizational Dynamics, 30, 310-324.

LIN, S.-C. \& HUANG, Y.-M. 2005. The Role of Social Capital in The Relationship between Human Capital and Career Mobility. Journal of Intellectual Capital, 6, 191-205.

PASS, C. 2004. Corporate governance and the role of non-executive directors in large UK companies: an empirical study. Corporate Governance: An International Review, 4, 52-63.

PFEFFER, J. \& SALANCIK, G. R. 1978. The External Control Organizations: A Resource Dependence Perspective, New York, Harper, and Row. 
PUGLIESE, A., MINICHILLI, A. \& ZATTONI, A. 2014. Integrating Agency and Resource dependence Theory: Firm Profitability, Industry Regulation, and Board Task Performance. Journal of Business Research, 67, 1189-1200.

REEB, D. M. \& ZHAO, W. 2013. Director Capital and Corporate Disclosure Quality. J. Account. Public Policy, 32, 191-212.

RICHARDSON, S. 2006. Over-Investment of Free Cash Flow. Review of Accounting Studies, 11, 159-189.

SILALAHI, U. 2009. Metode Penelitian Sosial, Bandung, PT. Refika Aditama.

WESTPHAL, J. D. 1999. Collaboration in The Boardroom: Behavioral and Performance Consequences of CEO-Board Social Ties. The Academy of Management Journal, 42, 7-24.

WILLIAMS, M. 2001. Are Intellectual Capital Performance and Disclosure Practice Related? Journal of Intellectual Capital, 4, 215-226.

XIE, B., DAVIDSON III, W. N. \& DADALT, P. J. 2003. Earnings Management and Corporate Governance: The Role of The Board and The Audit Committee. Journal of Corporate Finance, 9, 295-316.

YAMIN, S. \& KURNIAWAN, H. 2011. Partial Least Square Path Modeling, Jakarta, Salemba Infotek.

YOUNG, M. N., PENG, M. W., AHLSTROM, D., BRUTON, G. D. \& JIANG, Y. 2008. Corporate Governance in Emerging Economies: A Review of the Principal Perspective. Journal of Management Studies, 45, 196-220.

ZAHRA, S. A. \& PEARCE, I. J. A. 1989. Boards of Directors and Corporate Financial Performance: A Review and Integrative Model. Journal of Management, 15, 291-334. 